\title{
The Socialization Genesis of Gender Roles
}

\author{
Steven Gerardi \\ Professor Emeritus for Sociology, New York City College of Technology, CUNY, New York, USA \\ Email: Tutti50wag@aol.com
}

How to cite this paper: Gerardi, S. (2019). The Socialization Genesis of Gender Roles. Sociology Mind, 9, 131-133.

https://doi.org/10.4236/sm.2019.92009

Received: March 5, 2019

Accepted: April 14, 2019

Published: April 17, 2019

Copyright $\odot 2019$ by author(s) and Scientific Research Publishing Inc. This work is licensed under the Creative Commons Attribution International License (CC BY 4.0).

http://creativecommons.org/licenses/by/4.0/

\begin{abstract}
This effort will examine Fredrick Engels' The Origin of the Family, Private Property, and the State, and, Margret Mead's Sex and Temperament in Three Primitive Societies for the genesis of gender roles (patterns of behavior found in males and females in society). Both social scientists view gender roles based in a different social process, and not a biological function.
\end{abstract}

\section{Keywords}

Gender Roles: Conflict Paradigm, Functionalist Paradigm, Fredrick Engle's, Margret Mead, Modes of Production, Sex Temperament, Resource Power Theory

\section{Introduction}

By comparing Fredrick Engels', The Origin of the Family, Private Property and the State (gender roles as a product of the changing economic conditions), with Margret Mead's Sex and Temperament in Three Primitive Societies (gender roles are the product of culture), hence socialization. This effort will first discuss Fredrick's Engels work, followed by the Anthropologist Margaret Mead's work as it relates to socialization of gender roles.

\section{Context: Gender Role Genesis}

In Fredrick Engels (2010) work entitled The Origin of the Family, Private Property and the State, gender roles are traced through stages of economic development or modes-of-production (MOPs). He further suggested that whomever holds the most resources in a relationship, has the most power in that relationship (or the Resource Power Theory/RPT). He identified three forms of MOPs: 1) Savagery, 2) Barbarism, and 3) Civilization. Indeed, within each MOP there is a direct effect on the Resource Power Theory, changing gender role status in society. 
In the Savagery MOP or Hunting and Gathering, property was communal. Characterized by males hunted game, and females gathered fruits, roots and nuts. Hence, females held high status because they contributed equally to the survival of the group. No one sex held the RPT. Also characterize by the absence of private property, hence the absence of monogamy.

In Barbarism or Agricultural MOP, humanity breeds domestic animals and grows crops. Females lost their status with the rise of private property. During this MOP private property, marriage and reproduction all become linked due to inheritance patterns (the oldest male child inherits his father's wealth, status, and power), creating patriarchal domination.

During the Civilization MOP or Industrialization humanity moves toward mechanized forms of work. The family is the pairing group with one legal primary female, or monogamy. Females remain socially inferior because most factory workers during the late 1800 s and 1900s were displaced farmers from the Agricultural MOP, therefore carrying over the male dominate mindset.

Of course, Engels could not see into the future, thus another MOP must be added-that of the Post-Modern MOP. This period is marked by the growing need for a skilled educated work force. Indeed, in the USA today there are more females than males enrolled in college. Recent data suggest that American women are 33 percent more likely to complete a Baccalaureate degree or greater. Furthermore, males are more likely to drop-out of High School, with a small minority earning a GED.

Although during the start of the post-modern MOP males earn more income than females, this effort suggests that in the future these income differences will become a thing of the past (based on these educational data).

In Margaret Mead's (2011) work on cross cultural variations in New Guinea, entitled Sex and Temperament in Three Primitive Societies laid the groundwork for much of the research and scholarship for the study of gender roles. This work suggested that culture and not biological factors account for gender roles. Hence, there is no natural gender temperament or role associated with males and females. Culture defines how we see ourselves as males or females, maintaining stability in the relationship.

Mead identified three tribes with different "sex temperaments" or gender roles, a) Arapesh, b) Mundugumore and, c) Tchamboli (Yorberg, 2001), Family Relations: A Global View, Prentice Hall).

The Arapesh Tribe were a mild-mannered group with no idea of gender roles. They expected males and females to be gentle and socially equal. Additionality, males and females equally contributed to child rearing process, fostering social equality among the sexes.

The Mundugumore Tribe were a fierce people with much hostility among the genders. Children were considered rivals to the parents, with minimal parental care. The males had equal claim over females, giving them the right to exchange their sisters and daughters for younger wives.

The Tchamboli Tribe females were socially dominate. They hunted for game 
and were the protectors of the tribe. Males exhibited what may be seen today as female like qualities (adorned themselves with colorful clothing, jewelry, and so on). The male also displayed labor pains when the mate was giving birth to offspring. This cultural behavior was necessary to protect his mate's social status in that group, (by not displaying weakness). This type of behavior sociologist referred to as a social safety valve role.

\section{Conclusion}

The American Sociologist Talcott Parson defined Functionalism as parts of society (family, education the economy), are structured to maintain social equilibrium. If a part of society is dysfunctional, (it is not maintaining social balance), all other parts associated with the dysfunctional part, becomes dysfunctional as well (Gerardi, 2010).

Therefore, in the case of Mead's work, individuals in society will always approximate the gender role patterns of their culture, maintaining social balance between the sexes.

On the other hand, the Conflict paradigm suggests that the force behind gender roles development throughout history is the changing economic conditions in society, thus male/female relationships are based in hierarchies of power where both males/females are always opposing one another for what they conceive to be scarce resources such as power, authority, or wealth. Therefore, the Conflict paradigm suggests that the force behind the gender role genesis is the struggle for power (RPT).

Lastly, for these social scientist biological factors have no influence on the genesis of gender roles (gender roles are patterns of behavior expected of males and females) rather, the genesis is the product of socialization (Gerardi, 2012).

\section{Conflicts of Interest}

The author declares no conflicts of interest regarding the publication of this paper.

\section{References}

Engels, F. (2010). The Origin of the Family, Private Property and the State. NY: Penguin Group ( $1^{\text {st }}$ Published in 1884).

Gerardi, S. (2010). A Brief Survey of the Sociological Imagination ( $3^{\text {rd }}$ Edition). KendallHunt Publishing.

Gerardi, S. (2012). Social Change, Historical Modes-of-Production and the Tendency toward Capital Concentration. Sociology Mind, 2, 247-250.

https://doi.org/10.4236/sm.2012.23032

Mead, M. (2001). Sex and Temperament: In Three Primitive Societies Paperback. Harper Perennial Publication ( $1^{\text {st }}$ Published in 1935).

Yorberg, B. (2001). Family Relations: A Global View. Prentice Hall. 